Original Article

\title{
Impact of alien fishes on the distribution pattern of indigenous freshwater fishes of Punjab, Pakistan
}

\author{
Impacto de peixes invasores no padrão de distribuição de peixes de água doce em \\ Punjab, Paquistão
}

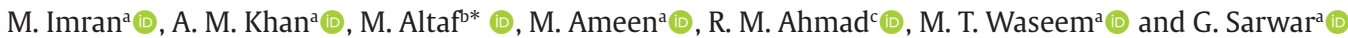 \\ aUniversity of the Punjab, Institute of Zoology, Lahore, Pakistan \\ ${ }^{\mathrm{b}}$ The Islamia University of Bahawalpur, Department of Forestry, Range and Wildlife Management, Bahawalpur, Pakistan \\ c University of Okara, Department of Zoology, Okara, Pakistan
}

\begin{abstract}
Pakistan is the country with mega freshwater fish diversity of native and alien species. In the presence of enormous native fishes varies species of exotic fishes have been introduced into the freshwater bodies of Pakistan which are competing with native freshwater fish fauna and making them deprive of food and habitat as well. Intentional or accidental introductions of animals, plants and pathogens away from their native niche is considered as major leading problem for biodiversity of invaded habitat. Three years study (from January 2017 to December 2019) was conducted in freshwater bodies of Province Punjab, Pakistan. Study was designed to know exotic species impacts on the distribution of native species of fishes. During current survey a total of 68 (indigenous and exotic) fish species belonging to 14 families were recorded from head Qadirabad, head Baloki, Islam headworks and Rasul barrage. Statistical analysis showed that Shannon-Wiener diversity index was the highest (1.41) at both Rasul barrage and Islam headworks but, invasive species were present in very less number in these study sites i.e. Oreochromis mozambicus, O. niloticus, Hypophthalmichthys nobilis, Carassius auratus, Ctenophryngdon idella, Cyprinus carpio and H. molitrix. The diversity index showed that comparatively low diversity was present in both area head Qadirabad (1.30) and head Baloki (1.4) due to high pressure of invasive species. Direct observation of species and statistical analysis showed that aliens' species produced negative impact on the local fish fauna diversity, evenness, and numbers. It is concluded that many factors are impacts on the diversity of native fishes, but alien (invasive) species also play a major role to reduction of native species, because aliens' species produce competition for native species. So it is urgent need to analysis the aliens and native food web and roosting sites in Pakistan, in future.
\end{abstract}

Keywords: competition, alien fishes, native, PCA, diversity.

\begin{abstract}
Resumo
O Paquistão é um país com ampla diversidade de espécies nativas e exóticas de peixes de água doce. Contudo, diversas espécies de peixes exóticos estão sendo introduzidas nos corpos de água doce paquistanês, as quais estão competindo com a fauna nativa de peixes, tornando-os privados de alimento e habitat. A introdução intencional ou acidental de animais, plantas e patógenos fora de seu nicho nativo é considerada o principal problema da biodiversidade do habitat recém-invadido. Assim, foi realizado um estudo de três anos, de janeiro de 2017 a dezembro de 2019, em corpos de água doce na província de Punjab, Paquistão. A pesquisa foi desenvolvida para conhecer os impactos de espécies exóticas na distribuição de espécies nativas de peixes. Durante a pesquisa, foi registrado um total de 68 espécies de peixes (nativas e exóticas), pertencentes a 14 famílias, nas nascentes dos rios Qadirabad, Baloki e Islam e na barragem de Rasul. A análise estatística mostrou que o índice de diversidade de Shannon-Wiener foi mais alto $(1,41)$ na barragem Rasul (RB) e na nascente do rio Islam (IH); e que a maioria das espécies introduzidas estava presente em um número muito menor, isto é, Oreochromis mossambicus, Oreochromis niloticus, Hypophthalmichthys nobilis, Carassius auratus, Ctenopharyngodon idella, Cyprinus carpio e Hypophthalmichthy smolitrix nessa área de estudo. Por outro lado, o índice Shannon-Wiener mostrou que a diversidade estava baixa nas nascentes dos rios Qadirabad $(1,30)$ e Baloki $(1,4)$ em razão da alta pressão de espécies invasoras. A observação direta das espécies e a análise estatística indicaram que as espécies invasoras produziram impacto negativo na diversidade, uniformidade e números de peixes da fauna local. Conclui-se que muitos fatores impactam na diversidade de peixes nativos, mas as espécies exóticas (invasoras) também desempenham um papel importante na redução das espécies nativas, em razão da competição existente entre elas. Portanto, é urgente uma análise futura das espécies invasoras e da teia alimentar nativa no Paquistão..
\end{abstract}

Palavras-chave: competição, peixes invasores, nativo, PCA, diversidade.

*e-mail: altaf_mughal450@yahoo.com

Received: 15 May 2020 - Accepted: 04 Aug. 2020

This is an Open Access article distributed under the terms of the Creative Commons Attribution License, which permits unrestricted use, distribution, and reproduction in any medium, provided the original work is properly cited. 


\section{Introduction}

Intentional or unintentional introductions of living organisms away from their native habitat is considered as main problem for living organisms of their newly invaded habitat (Sala et al., 2000). All over the world biodiversity in aquatic ecosystem is changing (Bassem, 2020) and depleted seriously as the result of pollution, habitat loss, introduction of alien species, over exploitation and also all other anthropogenic impacts (Altaf, 2016; Khan et al., 2011). Fishes act as keystone species in water bodies to determine the distribution pattern of other organisms along with water quality and ecosystem health as an indicator (Moyle and Leidy, 1992). The introduction of alien fishes has global concern regarding the extinction of native fish fauna as a result of competition at various levels (Kumar, 2000). The invasion risk is not only the change in quality and distribution pattern of indigenous fauna but also affects the socio-economic parameters of human community depending upon particular aquatic ecosystem to survive (Puth and Post, 2005).

Though alien species introductions are usually done with the most excellent of aims but these species have subjected local fish fauna to new predators or competitors that they are not capable to survive. The effects of introduced fish fauna on aquatic biodiversity will fall into two broad categories i.e. socio-economic and ecological (includes genetic and biological effects). The socio economic changes brought about by alien species in turn cause more ecological changes. Therefore a reduction in local fish species may be from direct impact of aliens' species or it may result from increased fishing pressure or changes in landscape use brought concerning by the occurrence of a recently established fish species (FAO, 1998; Khan et al., 2011).

World's largest canal system is found in Pakistan which consists of about 225 of wetlands having the area of 0.78 Million hectares with $26 \%$ costal wetland,74\% freshwater and Ramsar sites with 19 in numbers (Altaf et al., 2014). The province Punjab has five rivers and irrigation system consists of barrages, dams, canals and water ways. Few of the larger barrages in Punjab are Sukhar, Qadirabad, Khanki, Marala, Rasul, Taunsa and Chashma which make the Punjab as the rich and dominant source of aquatic biodiversity (Iqbal et al., 2017; Muhammad et al., 2019a; Muhammad et al., 2017b; Muhammad et al., 2019b).

A large number of data of fish fauna have been documented by large number of ichthyologist (Hussain et al., 2009; Khan et al., 2011; Mirza and Mirza, 2014; Mirza et al., 2011; Muhammad et al., 2017a; Muhammad et al., 2018). Due various purposes like sport fishing, aquatic weed and mosquito control as well as for yield enhancement several alien fish species have been introduced in Pakistan which includes eight species of warm water: Oreochromis niloticus, Oreochromis aureus, O. mozambicus, Hypopthalmicthys molitrix, H. nobilis, Ctenophryngdon idella, Carassius auratus and Cyprinus carpio along with two species of cold water: Onchorynchus mykiss and Salmo trutta (Khan et al., 2011). Present study planned to know the exotic fish species impact on the native fish species diversity in rivers of Punjab, Pakistan.

\section{Material and Methods}

The current study was conducted from January 2017 to December 2019 (5:00 am to 9:00 am hours).

\subsection{Study area}

Data were collected from four selected sampling sites i.e. head Qadirabad (at river Chenab), head Baloki (at river Ravi), Rasul barrage (at river Jhelum) and Islam headworks (at river Sutlej) (Figure 1). Data were collected with the help of fisherman and local people by using different nets of specific mesh sizes viz. gill net with $10 \mathrm{~m}$ length, $1.6 \mathrm{~m}$ height and mesh from 15-110 mm knot-knot.

\subsection{Climate}

The climate of sampling sites mainly consists of winter $\left(2.5^{\circ} \mathrm{C}\right)$, spring, summer (sometimes more than $45^{\circ} \mathrm{C}$ ) and autumn. Rainfall was noted from 40 to $110 \mathrm{~mm}$ in over Punjab (Cheema and Hanif, 2013; Khan et al., 2011).

\subsection{Methodology}

Data were collected two times in month of January, April, August and December in 2017 to 2019. To prevent from further decay samples (with large size) were injected with $10 \%$ formalin and preserved in plastic jars containing buffered formalin solution (Pervaiz et al., 2018). Samples were immediately photographed and identified up to species level using appropriate identification keys (Mirza, 2004).

\subsection{Statistical analysis}

Different statistical indices were used to analysis the data as; Shannon-wiener diversity Index and Evenness, while PCA was used to know the multivariate correlation.

Shannon-wiener Diversity Index (H') was calculated as (Shannon and Weaver, 1949);

$$
H^{\prime}=-[\Sigma P \ln P]
$$

Where, $\mathrm{H}^{\prime}$ = Diversity Index

Evenness (E) of fishes was calculated as (Pielou, 1966).

$$
\mathrm{E}=\mathrm{H}^{\prime} / \ln \mathrm{S}
$$

Where $S$ is total number of fish species

Past (Version 3) statistical tool was used to know the PCA value (Hammert et al., 2001).

\section{Results and discussion}

During the study period total of 68 species and 14 families and 2674 individuals of fish fauna were documented, out of total 579 from head Qadirabad, 616 from head Baloki, 838 from Islam headworks and 641 from Rasul barrage were reported (Figure 2,3 and Table 1).

Statistical analysis shown that Shannon-Wiener diversity index $\left(\mathrm{H}^{\prime}\right)$ was the highest (1.41) at both RB and $\mathrm{IH}$, because most of the aliens' species were absent or present in very less number i.e. O. mozambicus, O. niloticus, Hypophthalmichthy snobilis, Carassius auratus, 


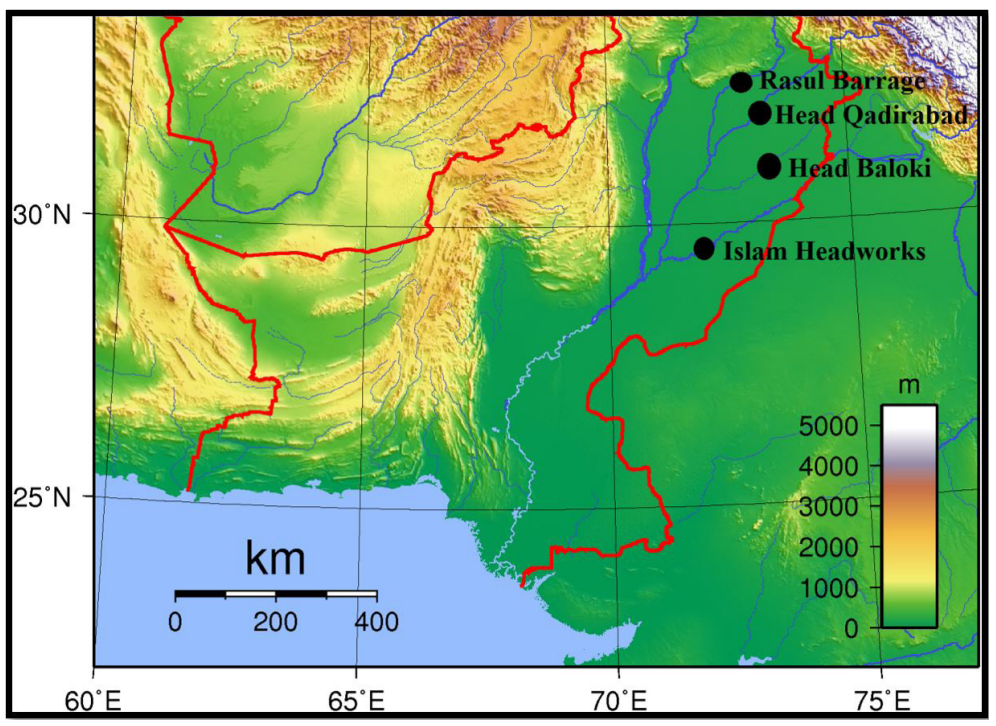

Figure 1. Map of sampling sites along with four sampling sites i.e. Head Qadirabad (HQ), Head Baloki (HB), Islam Headworks (IH) and Rasul Barrage (RB).

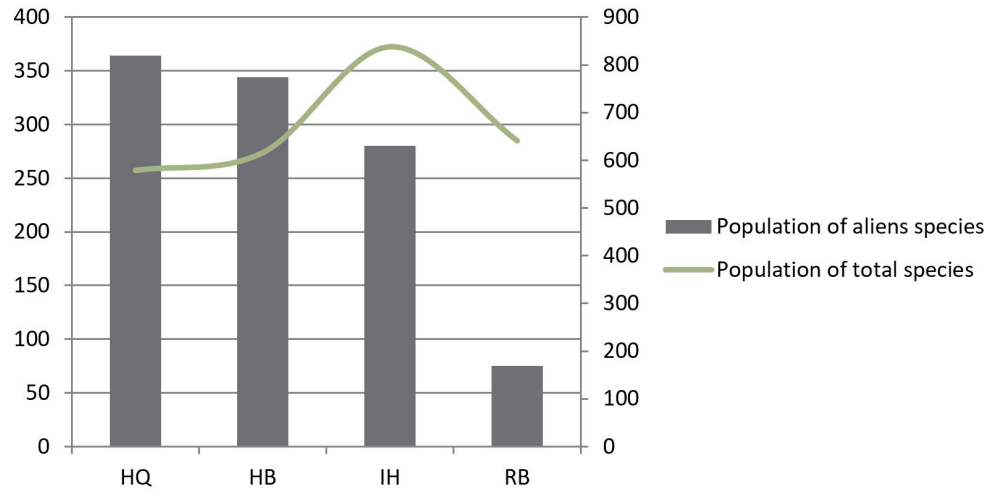

Figure 2. Graph shows that aliens' population impact on the native fish population.

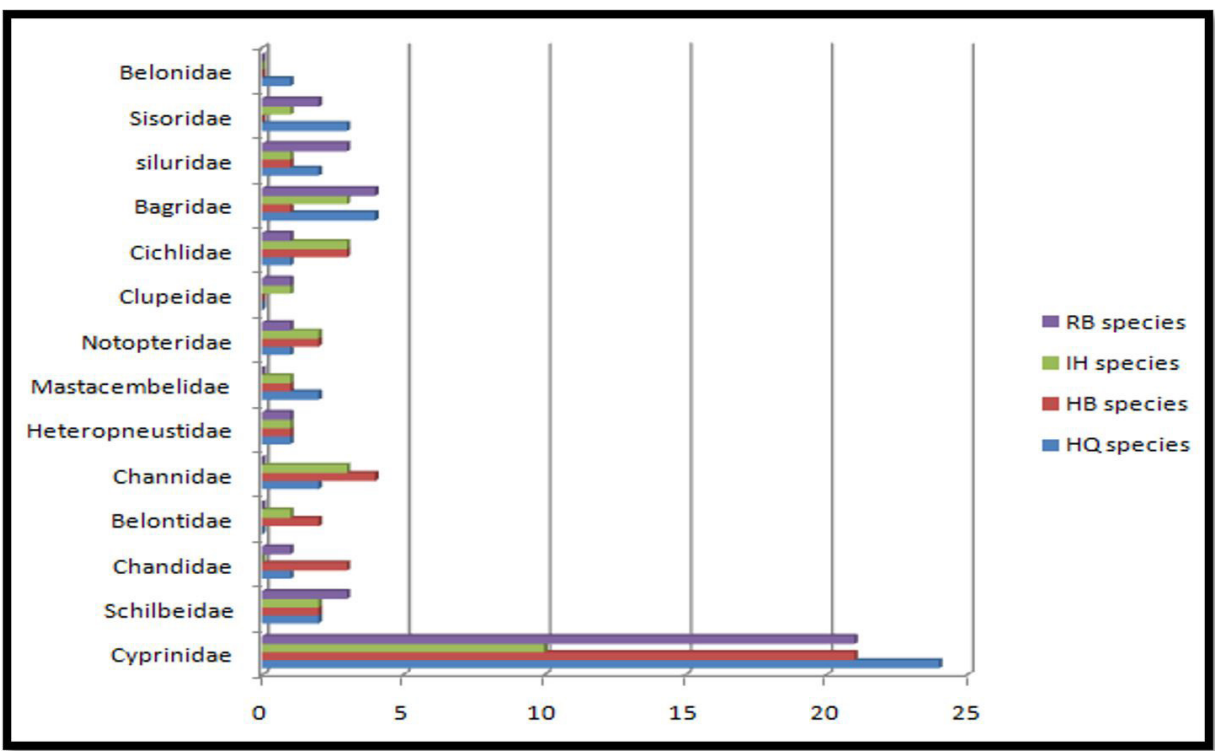

Figure 3.Families of fish species documented during surveys. 


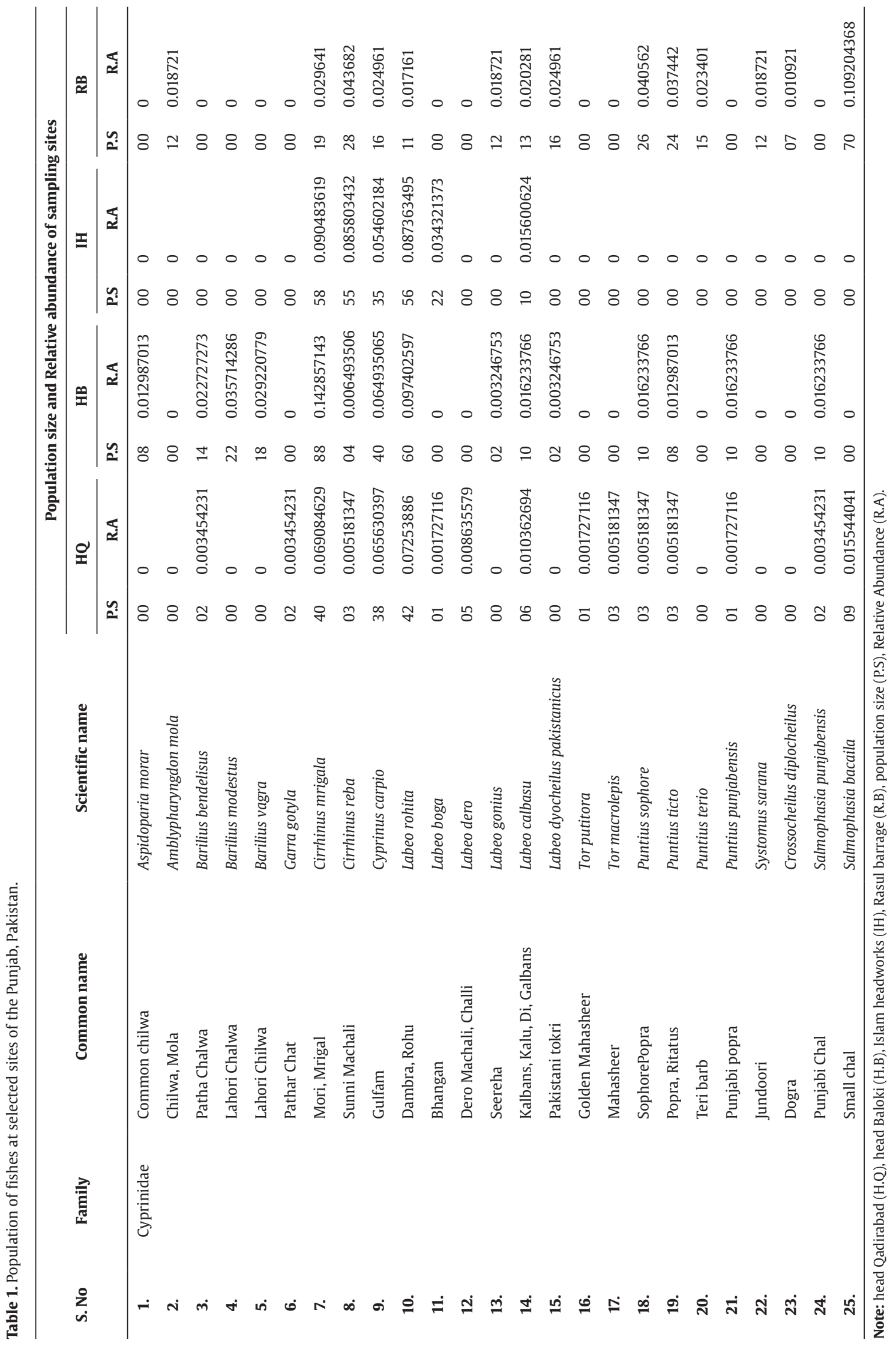




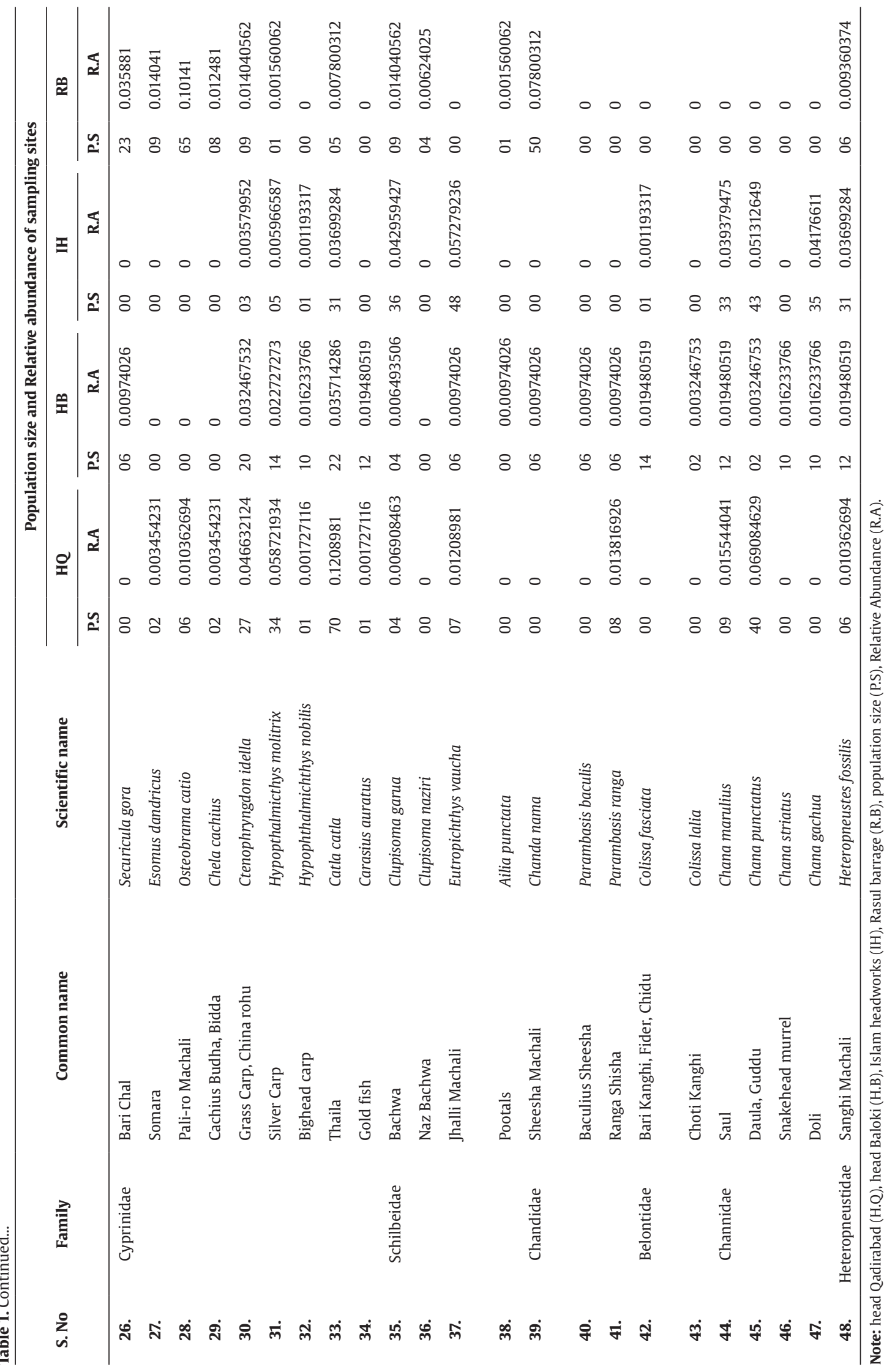




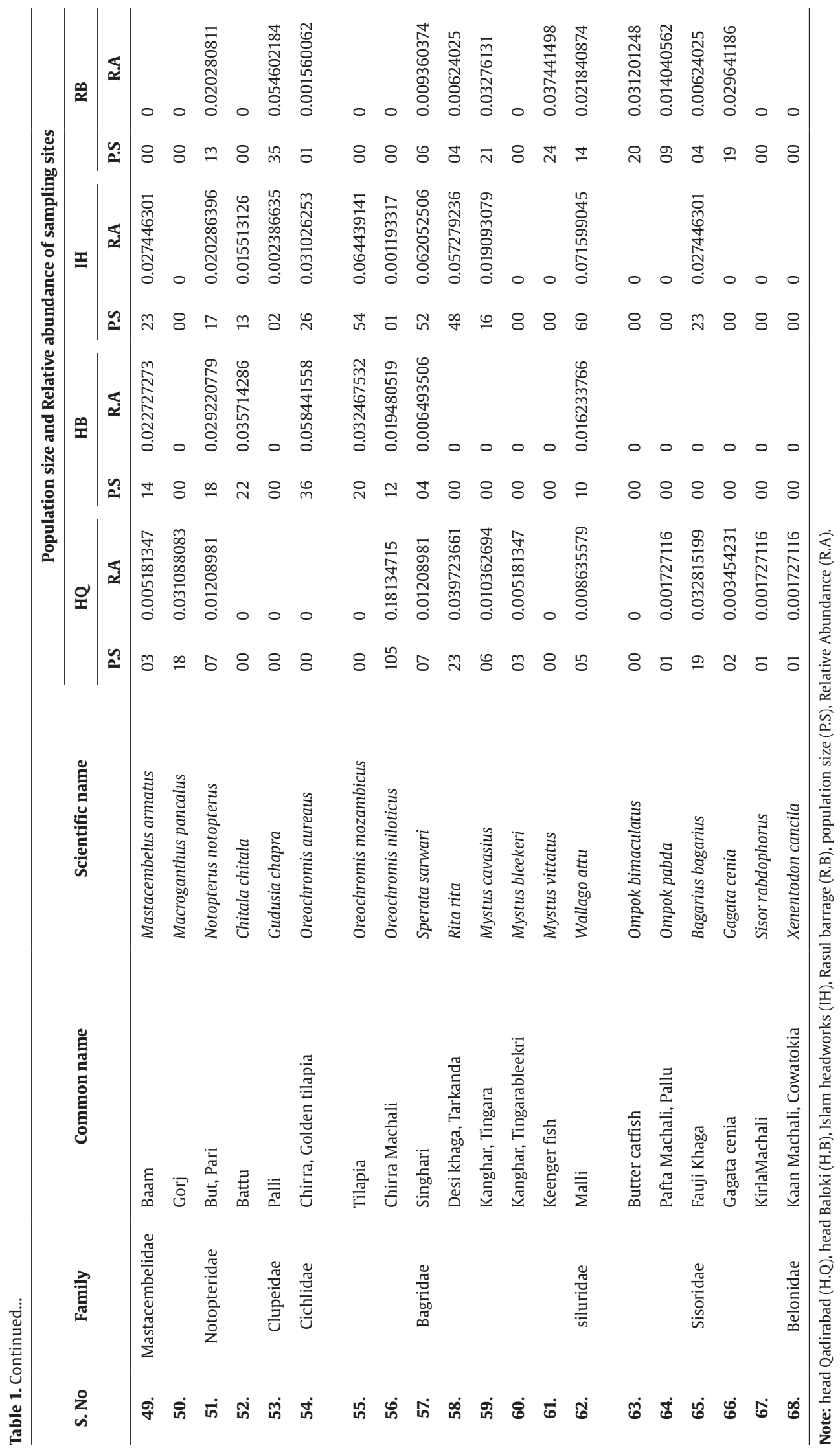


Ctenophryngdon idella, Cyprinus carpio and H. molitrix in this study area (Table 1). While on the other hand observed that diversity index comparatively low in both areas i.e. head Qadirabad (1.30) and head Baloki (1.4), due to high pressure of invasive species. Similarly, statistical analysis shown that Evenness diversity index (E) was the highest (1.0) at Islam headworks (IH) in this study area. While "E" shown that comparatively low diversity was present in these area RB (0.9) and HQ (0.9). Because highest alien species pressure was present, therefore lowest evenness was recorded in $\mathrm{HB}(0.8)$. While the highest population was also noted at $\mathrm{IH}(\mathrm{n}=641)$, the second highest was at head Qadirabad (16), while comparatively less population recorded at $\mathrm{HB}$ (616) and $\mathrm{RB}$ (679). Direct observation of species and statistical analysis shown that aliens species have negatively impact on the local fish fauna diversity, evenness and numbers (Table 2 and Figure 2).

Aliens' fish species were introduced for different purposes and different years, e.g. O. mozambicus was introduced in 1951 and 1954 from Thailand, Indonesia and Egypt in Pakistan. This is generalist feeder that mainly feeds of detritus and phytoplankton preferably, while fish and its larvae are also reported from gut contents which are the reason of competition between alien and native fishes. Nesting and fertilization occurs in shallow water (Naik, 1973). O. niloticus was introduced in 1985 from Egypt in Pakistan. This species generalist and produces negative impacts on native fishes. $O$. niloticus constructs nest in shallow water. Mother is mouth breeder and also feed fish and its larvae (De Silva, 2004).

C. auratus was introduced in Pakistan, while year and name of country from where import this species is not unknown (Table 3). Compete with native fish fauna because of generalist feeder, intense breeding capacity and plastic to changing environment in wild habitat (Naik, 1973). C. idella was introduced in 1964 from China in Pakistan. Mainly feeds on aquatic weeds that are bedding and shelter ground for different indigenous fishes, amphibians and other invertebrates. Alter the physiochemical properties of water that may hard area for other fishes (FAO, 1970). C. carpio was introduced in 1964 from United Kingdom and Thailand in Pakistan (FishBase, 2003). H. molitrix was introduced in 1964 in Pakistan. Silver carp competes with surface feeder (planktivorus) C. catla in captivity while in wild compete with fishes of similar feeding habits both for space and food due to plasticity in its nature (FAO, 1970).

Table 2. Statistical analysis based on ichthyofauna diversity from freshwater bodies of Punjab.

\begin{tabular}{clcccc}
\hline & \multicolumn{1}{c}{ Indices } & \multicolumn{3}{c}{ Study sites } \\
\cline { 3 - 6 } S. No & & H.Q & H.B & I.H & R.B \\
\hline 1. & Species Number (N) & 44 & 42 & 29 & 38 \\
2. & Shannon Index (H') & 1.30 & 1.40 & 1.41 & 1.41 \\
3. & Evenness (E) & 0.80 & 0.90 & 1.00 & 0.90 \\
4. & Total fish species numbers & 579 & 616 & 838 & 641 \\
5. & Aliens species numbers & 294 & 322 & 249 & 70 \\
\hline
\end{tabular}

Table 3. Critical and comprehensive review on exotic fishes in Pakistan

\begin{tabular}{|c|c|c|c|c|c|c|}
\hline S. No & Fish specie & $\begin{array}{l}\text { Imported } \\
\text { from }\end{array}$ & Years & Purposes of introduction & $\begin{array}{l}\text { Current } \\
\text { status }\end{array}$ & Reference \\
\hline 1 & O. niloticus & Egypt & 1985 & $\begin{array}{l}\text { To promote Aquaculture practices } \\
\text { in saline and brackish water }\end{array}$ & Established & $\begin{array}{l}\text { (De Silva, } \\
\text { 2004) }\end{array}$ \\
\hline 3 & $\begin{array}{c}\text { O. } \\
\text { mozambicus }\end{array}$ & $\begin{array}{c}\text { Thailand, } \\
\text { Indonesia and } \\
\text { Egypt }\end{array}$ & $\begin{array}{l}\text { 1951and } \\
954\end{array}$ & $\begin{array}{c}\text { To accelerate aquaculture } \\
\text { capacity of saline water reservoirs }\end{array}$ & Established & (Naik, 1973) \\
\hline 5 & C. auratus & Unknown & Unknown & $\begin{array}{l}\text { To promote ornamental } \\
\text { aquaculture in Pakistan }\end{array}$ & Established & (Mirza, 2003) \\
\hline 6 & C. idella & China & 1964 & $\begin{array}{c}\text { To enhance aquaculture } \\
\text { production and control aquatic } \\
\text { weeds }\end{array}$ & Not confirm & $(\mathrm{FAO}, 1970)$ \\
\hline 7 & C. carpio & $\begin{array}{l}\text { UK and } \\
\text { Thailand }\end{array}$ & 1964 & $\begin{array}{l}\text { To enhance sport fishing and } \\
\text { aquaculture production }\end{array}$ & Established & $\begin{array}{l}\text { (FishBase, } \\
\text { 2003) }\end{array}$ \\
\hline 8 & H. molitrix & Unknown & 1964 & $\begin{array}{l}\text { To accelerate aquaculture } \\
\text { production, sports and fish } \\
\text { angling }\end{array}$ & Not confirm & $(\mathrm{FAO}, 1970)$ \\
\hline 9 & H. nobilis & $\begin{array}{l}\text { China and } \\
\text { Nepal }\end{array}$ & $\begin{array}{c}1974-75 \\
\text { and 1982- } \\
83\end{array}$ & $\begin{array}{l}\text { To accelerate aquaculture } \\
\text { production, sports and fish } \\
\text { angling }\end{array}$ & Not confirm & $\begin{array}{l}\text { (Mahboob } \\
\text { and Sheri, } \\
\text { 1997) }\end{array}$ \\
\hline
\end{tabular}


H. nobilis was introduced in 1974 and 1982 from China and Nepal respectively in Pakistan. Bighead carp competes with other planktivorus species both for space and food due to plasticity in nature in changing environment (Mahboob and Sheri, 1997).

The two axes of the PCA explained $70 \%$ of difference in fish diversity (PC 1: 50\%; PC 2: 20\%). Variables loading onto Axis 1 included HQ $(r=0.54), \mathrm{HB}(r=0.46)$, IB $(r=0.70)$, and $\mathrm{RB}(r=0.02)$. The direction of these associations shows that Axis 1 synthesized the response of the fish community to exotic species impact. Study areas also loaded into Axis 2 (HQ: $r=0.78$, HB: $r=0.009$, IB: $r=-0.61$, and RB: $r=-0.12$ ). Both Axes are not correlated with each other; likewise, fish diversity patterns extracted by PC 2 are not related to those explained by Axis 1 . Almost all variables landscapes do not resemble considerably with other PCA component showing that aliens species impacts were the principal factor determining the fish community. Axis two is divided into two sections, one section consists of RB and IB, which are negatively correlate with alien species; while HQ and HB are positively correlated with aliens species (Figure 4 and 5). The most of alien species are seen near HQ and HB i.e. chira, thaila, Silver carp and grass carp (Figure 4). These results are supported by Altaf (2016).

Many species of fish are introduced into India for aquaculture, ornamental and many other purposes. In due lessons of time a small number of the fish species manage to flee into wild and turned as invasive to the system. Some of alien fish species which foundation of vast damage to the biodiversity and economy (Sandilyan et al., 2018)

Native fishes including Catla catla, Labeo rohita, Cirrhinus mrigala and Labe ocalbasu are economically important, detritivorus and vegetarian. Alien fishes are mainly omnivore in nature which feed on aquatic vegetation and planktons mainly. Fish larvae and small fishes along detritus is preferable food for 0 . aureus (alien

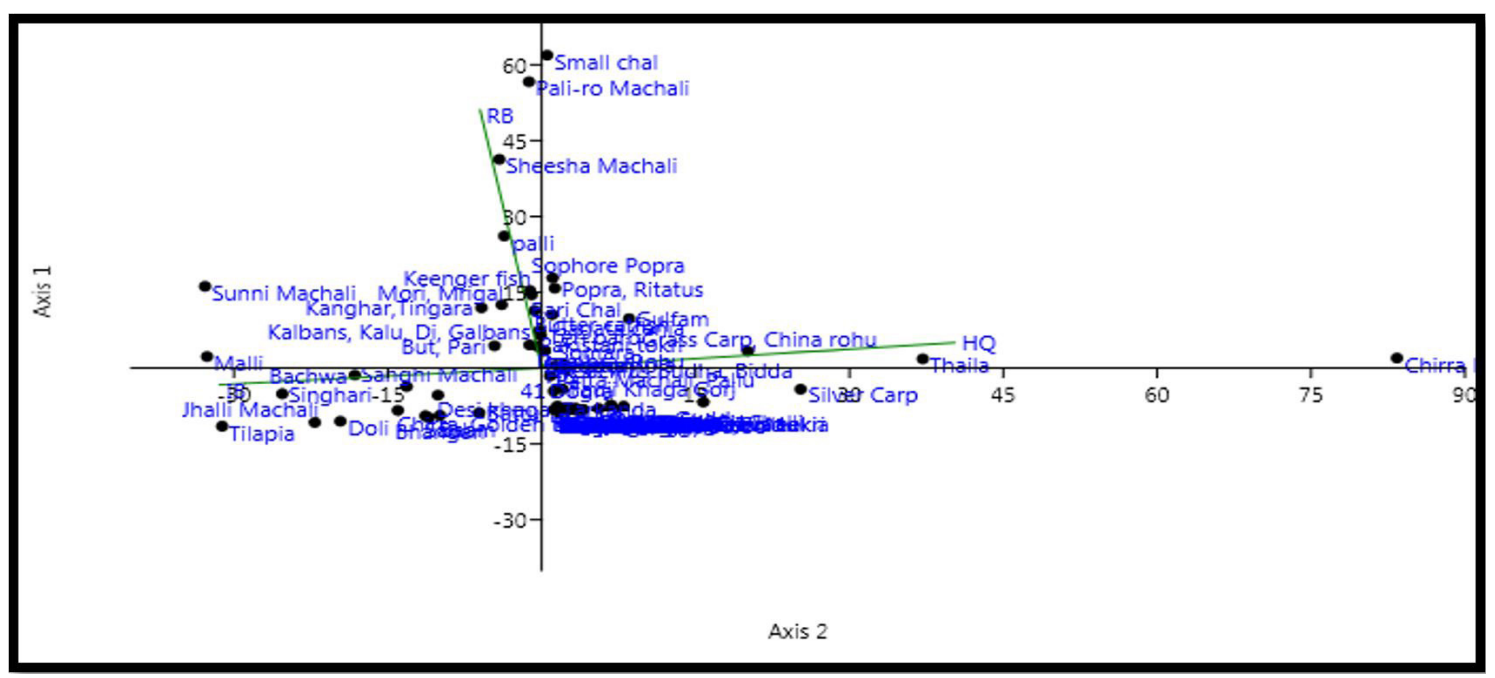

Figure 4. Analysis of aliens' fish species impact on the diversity of native fish species through PCA.

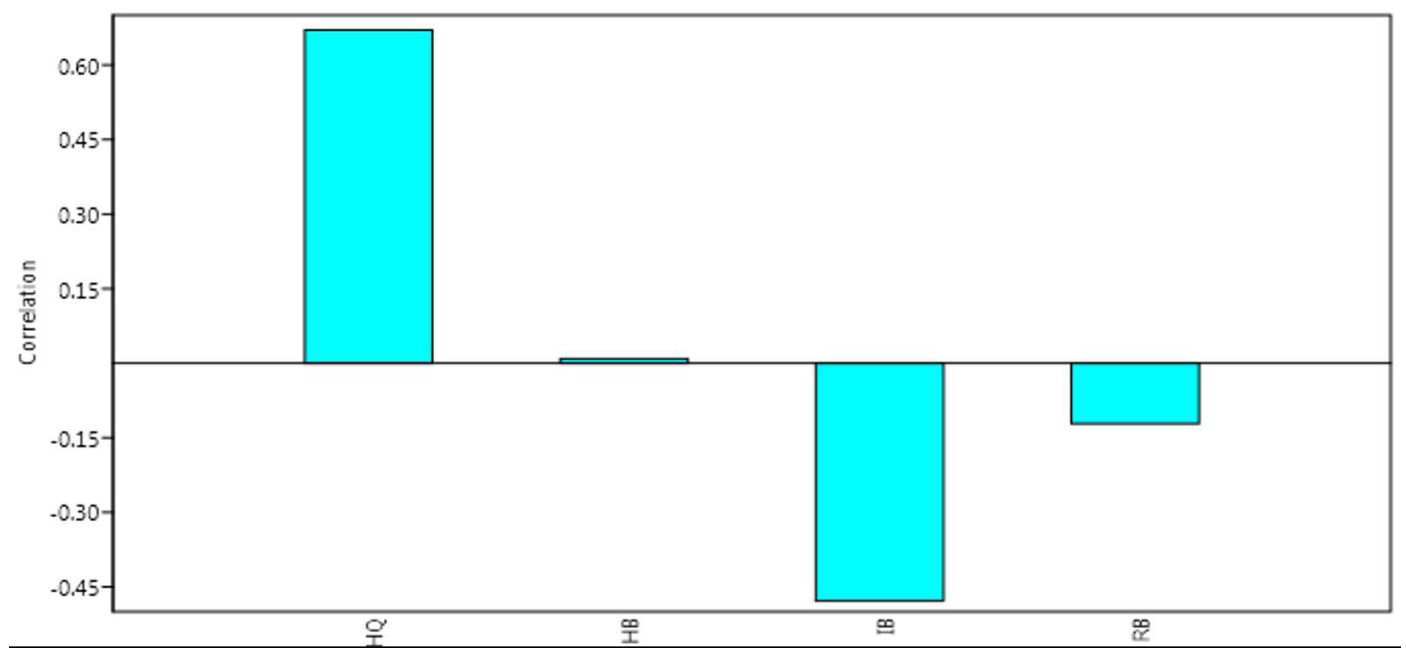

Figure 5. Loading of PCA showed that correlation among the four sites. 
fish) which makes it opportunistic based on habitat and source availability (Welcomme and Vidthayanon, 2003). McNeely (2001) stated that introduction of exotic fishes including Oreochromis mozambicus, Ctenophryngdon idella, Hypophthalmichthys nobilis and Cyprinus carpio in Philippine lakes caused the extinction of local fish fauna. Khan et al. (2011) reported that a major threat to fish diversity conservation is the introduction of alien fishes because Oreochromis aureus was imported from Egypt for the development of aquaculture in Pakistan but it become completely invaded due to the direct food competition with native fish community that may pose serious threat while Grass carp and mosquito fish was introduced for the control of aquatic weeds and mosquito larvae respectively.

Scientist demonstrated that the competition between alien and native fish fauna of freshwater is at the level of fish distribution, population dynamics and food chain structure (Garber and Sullivan, 2006; Yan et al., 2001). (IUCNP, 2004) found the impact of alien fish on native fish fauna from threatened to endangered and directed to rehabilitate the endangered species and habitat change in Pakistan. Taylor et al. (1984) suggested that impact of alien fishes on native fish fauna is in the form of trophic change including competition, predation, alteration in food web structure, parasites addition and disease induction. Ichthyologist documented that Cyprinus carpio as pest because it uproots the vegetation from water body causing increase in turbidity and clarity of water reduces (Wahab et al., 1995). Cambray (2003) narrated that the effect of alien fishes is unpredictable in space and time with the addition of few species may expire many indigenous species of fish worldwide. It is documented that in Yunnan (China) about 33 percent of indigenous fishes are extinct out of the total fish species (432 species), due to the dam construction, over fishing, water pollution and introduction of alien fishes is the main factor of extinction (Chen et al., 1998).

\section{Conclusion}

It is concluded that lot of factors which are impacts on the diversity of native fishes, but alien (invasive) species also play a major role in reduction of native species, because aliens species may produce competition for native species in different ways e.g. food, roosting sites and shelter. So it is urgent need to analysis the aliens and native food web and roosting sites in Pakistan, in future.

\section{References}

ALTAF, M., 2016. Assessment of avian and mammalian diversity at selected sites along river Chenab. Lahore-Pakistan: University of Veterinary and Animal Sciences, 197 p. PhD Thesis.

ALTAF, M., JAVID, A., and UMAIR, M. 2014. Biodiversity of Ramsar sites in Pakistan.Republic of Moldova:LAP.

BASSEM, S.M., 2020. Water pollution and aquatic biodiversity. Biodiversity International Journal, vol. 4, no. 4, pp. 10-16.

CAMBRAY, J.A., 2003. Impact on indigenous species biodiversity caused by the globalisation of alien recreational freshwater
fisheries.Hydrobiologia, vol. 500, no. 1-3, pp. 217-230. http:// dx.doi.org/10.1023/A:1024648719995.

CHEEMA, S. and HANIF, M., 2013. Seasonal precipitation variation over Punjab province.Pakistan Journal of Meteorology Vol, vol. 10, no. 19 , pp. $61-82$

CHEN, Y., YANG, J. and LI, Z., 1998. The diversity and present status of fishes in Yunnan Province.Chinese Biodiversity, vol. 6, no. 4, pp. 272-277.

DE SILVA, S.S.2004. Tilapias as alien aquatics in Asia and the Pacific: a review.Rome, Italy: Food \& Agriculture Org.

Food and Agriculture Organization of the United Nations- FAO,1970. Report on the regional seminar on induced breeding of cultivated fishes, Barrackpore, Cuttack and Bombay, India, 15 July-18 August 1969. Rome: FAO/UNDP (TA), 19 p., (2814).

Food and Agriculture Organization of the United Nations- FAO,1998. FAO Fish stat PC. Fishery Information, Data and statistics Unit. Rome, Italy:Food and Agriculture Organization of the United Nations.

FISHBASE [online],2003 [viewed 11 April 2020]. Available from: http://www.fishbase.org/home.htm.

GARBER, A.F. and SULLIVAN, C.V., 2006. Selective breeding for the hybrid striped bass (Moronechrysops, Rafinesquex M. saxatilis, Walbaum) industry: status and perspectives. Aquaculture Research, vol. 37, no. 4, pp. 319-338. http://dx.doi. org/10.1111/j.1365-2109.2005.01439.x.

HAMMERT, Q., HARPER, D.A.T. and RYAN, P.D., 2001. Past paleontological statistical software package for education and data analysis. Palaeontologia Electronica, vol. 4, no. 1, pp. 1-9.

HUSSAINA., QAZI, J.I., SHAKIR, H. A., MIRZA, M.R. and NAYYER, A.Q., 2009. Length-weight relationship, meristic and morphometric study of Clupisomanaziri from the river indus, Pakistan.Punjab University Journal of Zoology, vol. 24, no. 1-2, pp. 14-25.

IQBAL, M.M., ABBAS, S., IQBAL, K.J., HAIDER, M.S., ASHRAF, S., MUHAMMAD, N. and KHAN, A.M., 2017. Status of fish diversity of Islam Barrage, river Sutlej, Punjab, Pakistan.Journal of Wildlife and Ecology, vol. 1, no. 3

IUCNP, 2004. Conservation assessment and management plan workshop for freshwater biodiversity of pakistan.Abstracts from ZOOTAXA P, vol. 4, pp. 5.

KHAN, A., ALI, Z., SHELLY, S., AHMAD, Z. and MIRZA, M., 2011. Aliens; a catastrophe for native freshwater fish diversity in Pakistan.J Anim Plant Sci, vol. 21, pp. 435-440.

KUMAR, A.B., 2000. Exotic fishes and freshwater fish diversity. Zoos' Print Journal, vol. 15, no. 11, pp. 363-367. http://dx.doi. org/10.11609/JoTT.ZPJ.15.11.363-7.

MAHBOOB, S. and SHERI, A., 1997. Growth performance of major, common and some Chinese carps under composite culture system with special reference to pond fertilization. Journal of Aquaculture in the Tropics, vol. 12, pp. 201-208.

MCNEELY, J.A., 2001. Global strategy on invasive alien species. Cambridge, UK: IUCN

MIRZA, M.R., 2003. Checklist of freshwater fishes of Pakistan.Zoological Society of Pakistan

MIRZA, M.R., 2004. Freshwater fishes of Pakistan. Pakistan: Urdu Science Board. pp. 1-244.

MIRZA, M.R. and MIRZA, Z.S., 2014. Longitudinal zonation in the fish fauna of the indus river in Pakistan.Biologia, vol. 60, no. 1, pp. 149-152.

MIRZA, Z.S., MIRZA, M.R., MIRZA, M. and SULEHRIA, A., 2011. Ichthyofaunal diversity of the river Jhelum, Pakistan.Biologia, vol. 57, no. 1-2, pp. 23-32. 
MOYLE, P.B. and LEIDY, R.A., 1992. Loss of biodiversity in aquatic ecosystems: evidence from fish faunas Conservation Biology. Boston: Springer. pp. 127-169.

MUHAMMAD, N., KHAN, A.M., ASHRAF, S., HAIDER, M.S., RASHEED, Z. and IQBAL, K.J., 2019a. Statistical analysis of fish diversity of Rasul Barrage, Punjab, Pakistan.Journal of Wildlife and Ecology, vol. 3, no. 4, pp. 6-12.

MUHAMMAD, N., KHAN, A.M., IQBAL, K.J., HAIDER, M.S., ASHRAF, S., ANSARI, Z.S., CHATTHA, S.A., ABBASI, A.R. and YAQOOB, M., 2017a. Assessment of distribution and ethnocultural uses of the Baringo tilapia (Oreochromis niloticus) in Punjab, Pakistan. Journal of Wildlife and Ecology, vol. 1, no. 4, pp. 7-13.

MUHAMMAD, N., UMAIR, M., KHAN, A.M., ABBASI, A.R., KHAN, Q. KHAN, A. and AWAN, M.Z., 2017b. Assessment of the diversity and ethno-medicinal uses of the carps in Punjab, Pakistan. Journal of Wildlife and Ecology, vol. 1, no. 1, pp. 52-60.

MUHAMMAD, N., UMAIR, M., KHAN, A.M., YAQOOB, M., ASHRAF, S., HAIDER, M.S., CHATTHA, S.A., ANSARI, Z.S., RASHEED, Z., YAQOOB, M. and IQBAL, K.J., 2019b. Statistical analysis of freshwater fishes of head Khanki, Punjab, Pakistan.Journal of Wildlife and Ecology, vol. 3, no. 1, pp. 1-9.

MUHAMMAD, N., UMAIR, M., KHAN, A.M., YAQOOB, M., HAIDER, M.S., KHAN, Q. and ABBASI, A.R., 2018. Assessment of cultural uses of Mrigal carp (Cirrhinusmrigala) in Gujranwala division, Pakistan.Journal of Wildlife and Ecology, vol. 2, no. 1, pp. 1-9.

NAIK, I., 1973. Studies on Tilapia mossambica Peters in Pakistan. Pakistan Journal of Agricultural Sciences, vol. 24, no. 1, pp. 47-76.

PERVAIZ, K., MIRZA, Z.S., SIDDIQUI, S., NAGHMA, K., WAHEED, S.H. and USMAN, K.2018. Studies on the fish biodiversity of River Ravi in Punjab Pakistan. Journal of Entomology and Zoology Studies, vol. 6, no. 1, pp. 1442-1448.

PIELOU, E.C., 1966. The measurement of diversity in different types of biological collections.Journal of Theoretical Biology, vol. 13, pp. 131-144. http://dx.doi.org/10.1016/0022-5193(66)90013-0.
PUTH, L.M. and POST, D.M., 2005. Studying invasion: have we missed the boat?Ecology Letters, vol. 8, no. 7, pp. 715-721. http:// dx.doi.org/10.1111/j.1461-0248.2005.00774.x.

SALA, O.E., CHAPIN, F.S.3rd ., ARMESTO, J.J., BERLOW, E., BLOOMFIELD, J., DIRZO, R., HUBER-SANWALD, E., HUENNEKE, L.F., JACKSON, R.B., KINZIG, A., LEEMANS, R., LODGE, D.M., MOONEY, H.A., OESTERHELD, M., POFF, N.L., SYKES, M.T., WALKER, B.H., WALKER, M. and WALL, D.H., 2000. Global biodiversity scenarios for the year 2100Science, vol. 287, no. 5459, pp. 1770-1774. http:// dx.doi.org/10.1126/science.287.5459.1770. PMid:10710299.

SANDILYAN, S., MEENAKUMARI, B., BIJUKUMAR, A. and MANDAL, R.,2018. A review on impacts of invasive alien species on Indian inland aquatic ecosystems. Chennai: National Biodiversity Authority, Centre for Biodiversity Policy and Law.

SHANNON, C. E. and WEAVER, W.1949. The mathematical theory of communication. Illinois:University of Illinois Press.

TAYLOR, N., COURTENAY JÚNIOR, W.R. and MCCANNJ.A., 1984. Known impacts of exotic fishes in the contintental United States. In: W.R.COURTENAY JÚNIOR, J.R.STAUFFER, eds. Distribution, biology and management of exotic fishes. Baltimore: Johns Hopkins University Press, pp. 322-373.

WAHAB, M., AHMED, Z., ISLAM, M.A., HAQ M. and RAHMATULLAH, S., 1995. Effects of introduction of common carp, Cyprinus carpio (L.), on the pond ecology and growth of fish in polyculture. Aquaculture Research, vol. 26, no. 9, pp. 619-628. http://dx.doi. org/10.1111/j.1365-2109.1995.tb00953.x.

WELCOMME, R. L. and VIDTHAYANON, C., 2003. The impacts of introductions and stocking of exotic species in the Mekong Basin and policies for their control. Cambodia: Mekong River Commission.

YAN, X., ZHENYU, L., GREGG, W.P. and DIANMO, L., 2001. Invasive species in China: an overview.Biodiversity and Conservation, vol. 10, no. 8, pp. 1317-1341. http://dx.doi. org/10.1023/A:1016695609745. 